\begin{tabular}{ccc}
\hline & International Journal of Current Research in \\
Biosciences and Plant Biology & Volume 5 • Number 1 (January-2018) • ISSN: 2349-8080 (Online) \\
\hline EXCELLENT \\
PUBLISHERS
\end{tabular}

\title{
Resilience of Hungry Rice Cropping in Sudano-Guinean Area of Mali: Case Study in the Village of Mandela
}

\section{Diakalia Sogodogo ${ }^{*}$, Béjamé Coulibaly², Moussa D. Sanogo ${ }^{3}$, Djigui Dembélé ${ }^{4}$ and Soumaila Sanogo 5}

${ }^{1}$ Agronome (Gestion des Ressources Naturelles)-Équipe Système de Production et de Gestion des

Ressources Naturelles/SRA Cinzana-IER MALI

${ }^{2}$ Agronome (Gestion Intégrée de la Fertilité des Sols) - ESPGRN/SRA Cinzana

3Sélectionneur Mil and Hungry Rice - SRA Cinzana

${ }^{4} \mathrm{MSc} /$ Agronome, ESPGRN/SRA Sikasso

${ }^{5}$ Technicien Vbservateur Villageois à Mandela

*Corresponding author.

\begin{tabular}{|c|c|}
\hline Article Info & ABSTRACT \\
\hline $\begin{array}{l}\text { Date of Acceptance: } \\
\text { 10 December } 2017 \\
\text { Date of Publication: } \\
\text { 06 January } 2018\end{array}$ & \multirow{3}{*}{$\begin{array}{l}\text { One study was conducted in the hosted village of the cooperative of women producing } \\
\text { hungry rice of Mandela in order to point out the manner of women to relay men in } \\
\text { hungry rice cropping and to analyze how they manage this crop in the context of } \\
\text { climate change. Information was collected with } 50 \% \text { of the cooperative members } \\
\text { selected randomly. Tools used were historical profile, matrix of climate change and } \\
\text { semi-structured interview. Results have shown men abandoning hungry rice cropping } \\
\text { since the drought of the early year of eighty's. Cropping continuity was insured by } \\
\text { women who produced hungry rice in one local inputs based cultural practice (use of } \\
\text { local genotypes, crop rotation and manure application). The two cropping systems } \\
\text { (rotation maize-hungry rice and hungry rice receiving } 2 \mathrm{t} \text { of mature/ha) have improved } \\
\text { yield by } 48 \% \text { and } 62 \% \text { respectively. The gross income generated by these cropping } \\
\text { systems are } 30000 \text { and } 60000 \text { FCFA/ha respectively. Hungry rice production } \\
\text { conditions are characterized by the absence of local source of input supply, selling } \\
\text { agricultural produce at low prices, specific use of female labor and low soil fertility. }\end{array}$} \\
\hline Keywords & \\
\hline $\begin{array}{l}\text { Climate change } \\
\text { Gross income } \\
\text { Hungry rice } \\
\text { Women } \\
\text { Yield }\end{array}$ & \\
\hline
\end{tabular}

\section{Introduction}

The agricultural sector is a very important development sector in the economies of countries in sub-Saharan Africa. In Mali, the economie repose on agriculture that uses $80 \%$ of the population and contributes up to $50 \%$ of GDP (Kieft et al, 1994). The agricultural population practices crops according to the regions. We have $81 \%$ of Mopti's farming population growing millet. Sorghum is highly produced by $68 \%, 67 \%$ and $63 \%$ of producers in Kayes, Koulikoro and Sikasso 
respectively. Maize and cotton are produced respectively by $91 \%$ and $86 \%$ of Sikasso producers (Ministry of Agriculture, 2007). Cereal production in the Sikasso region is $2,368,959 \mathrm{t}$ of cereals on $8,054,896 \mathrm{t}$ at the national level. It is in this region that we encounter the old Yanfolila and Sikasso hungry rice production basins, where 71,447 and 39,349 people live around the hungry rice respectively. Sikasso produced 1,614 t of hungry rice in a national production of 20,294 $\mathrm{t}$ (CPS / SDR, 2015). The productivity of farms throughout Mali's agricultural zone is low and intensification only concerns industrial crops.

The human population increases by $2.4 \%$ while production in the area increases by only $1.95 \%$, indicating strong population pressure on arable land (CILSS, 2012). Land used in agriculture, livestock and forestry is subject to degradation due to irrational exploitation, water and wind erosion (Consortium AGRECO, 2014). This degradation is also accentuated by the economic exploitation of the soils that are: deforestation, agricultural clearing, overgrazing, clearing for the construction of infrastructures and urbanization. Cropland in sub-Saharan Africa is characterized by nutrient poverty (Okalebo et al., 2007, Gichangi et al., 2007; Tabo et al., 2005) and the agricultural sector is affected by climate change (Ba, 2013).

Among the many other problems facing peasants, we can mention: the degradation of cultivated land, the disappearance of certain species of plants, animals in village lands, low access to the market of agricultural inputs and products. These problems directly threaten the substratum on which the livelihood of many rural communities rests. The years of good and bad agricultural seasons succeed one another in the Sudano-Sahelian zone and the peasants and poor peasants dominating the agriculture cannot sell large quantities of their production during the years of excess production. Roads are not available all year round and producers receive neither input credit nor campaign credit (CTA, 2014).

The major challenge is meeting the food needs of a growing population in the context of climate change. The adaptation of community life systems and farming systems is becoming a necessity to face this challenge. High-value rainfed crops such as cotton and corn are no longer sold at remunerative prices. The hungry rice, a traditional crop of low production, is cultivated in each of the village soils whatever the distribution of the rains. The near-permanence of the climate disruption could complicate the maintenance of food security in households that are mostly made up of small producers. Therefore, the option of resilient farming, pastoral and silvicultural systems would be imperative in mitigating the adverse effects of these changes.

This research is focused on the hungry rice cultivation by Mandela women who took over from men after the severe droughts of the $70 \mathrm{~s}$ and $80 \mathrm{~s}$. Our goal is to highlight the way in which women took over and analyze the how they manage the hungry rice cultivation in a context of climate change.

\section{Materials and methods}

\section{Study site}

The study was conducted in an area where women organized in hungry rice cooperatives grow hungry rice on soils of all kinds. These women have a long experience in organizing women producers. The area is part of a former hungry rice production pond that received rainfall amounts of $1390 \mathrm{~mm}$ and $1,022 \mathrm{~mm}$ in 2014 and 2015 respectively (Fig. 1). The normal rainfall of the area is $1,109.2 \mathrm{~mm}$. The month of August is the rainiest month with 16 to 20 days of rain. The soils are clay-silty in the shallows, sandy-clay on exiled lands.

The village of Mandela $(\mathrm{L}=-5.327999,1=$ 11.159269) counts 3445 inhabitants who are mainly Samogos an ethnic group straddling Mali, Ivory Coast and Burkina Faso. The village has no permanent access road all year round. It has a weekly market, a health center and a basic school. 


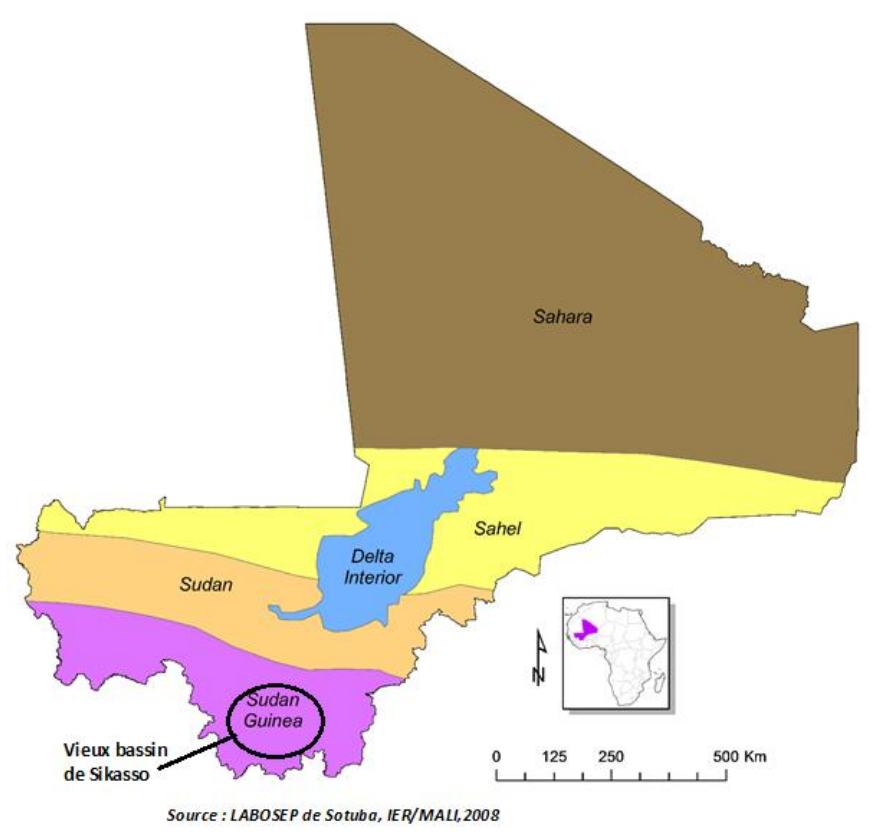

Fig. 1: Location of the study area in Mali.

\section{Data collection and analysis}

A plenary session was organized in the village followed by semi-structured interviews (ISS) with 40 producers selected at random from the hungry rice women's cooperative. The tools used in the data collection were: historical profile, ISS, the matrix of visible changes, the yield of hungry rice by cultivation technique was collected by a declarative survey with each of the women volunteers. The statistical analysis of the hungry rice yields and the illustration of results by tables and figures were made with the INSTAT V3.6 and Excel software. The economic evaluation focused on gross income in field hungry rice production. It is the purchase price of hungry rice at the time of harvest that was used in this assessment.

\section{Results and discussion}

\section{History of culture}

The farmers of Mandela practice hungry rice cultivation which has been their staple food for decades. Fig. 1 and 2 retrace the history of the hungry rice culture in the Mandela soils. This crop was disrupted by the droughts of the years 1973, 1984 which almost destroyed the production of hungry rice in some households. After these years of drought, farmers were much more attracted by the cultivation of new maize varieties from the corn project of the early 1980s which was technically and financially supported by the Malian Company for the Development of Textiles (CMDT). Men had more benefits in corn than in hungry rice.

The considerable decline in hungry rice production is a sign of the sensitivity of the traditional varieties used to the variation of the rainfall regime. From the drought of the 70s and $80 \mathrm{~s}$, the harvest of men no longer covered the needs of the family. This led the heads of household to gradually abandon the traditional hungry rice meals prepared every Friday. The local and surrounding communities became nostalgic for these banquet meals that made the village of Mandela proud. The hungry rice was the exaltation of a local know-how and the preservation of a cultural heritage. Evenings of balafon during which the bravery of the producers was sung, always marked the end of the harvests and decorticage of hungry rice. That's why women have not neglected the hungry rice culture. Nowadays, $85 \%$ of them cultivate 0.25 ha, $10 \%$ cultivate 0.5 ha and $5 \%$ have fields of one hectare of surface.

The hungry rice culture was resumed in the households thanks to a women's enterprise which enabled them to place the problem of the vulnerability of the hungry rice at the center of the reflections and strategies to be undertaken in each household. From the last great drought from 1984 to the present, there was no growing season without hungry rice cultivation (Fig. 2). Despite the frequent occurrence of dryness at the beginning or end of the rainy season from the 1990s, hungry rice gradually found its place in rotational rotations thanks to women's desire to maintain hungry rice in the diet of members of the family, household and community. It is by small plots often less than $1 / 4$ ha that women began hungry rice cultivation. Many households had consumed their seed for lack of food. Their seed supply was through the channel of friends, relatives, producers in other lands. The family labor used in hungry rice cultivation has been redeployed in maize cultivation, which has 
become the main cereal crop of the field. At the household level, the timing of maize and hungry rice activities coincide. To avoid the delay in the installation of the hungry rice culture, the women resort to the salaried workforce in their fields of hungry rice. All these provisions helped to make hungry rice cultivation, a women's activity from 1986 onwards.

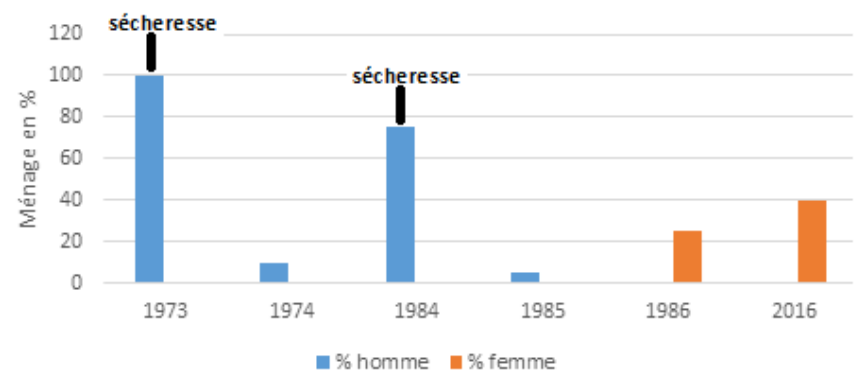

Fig. 2: Household-male and female rates in households practicing hungry rice cultivation Mandela.

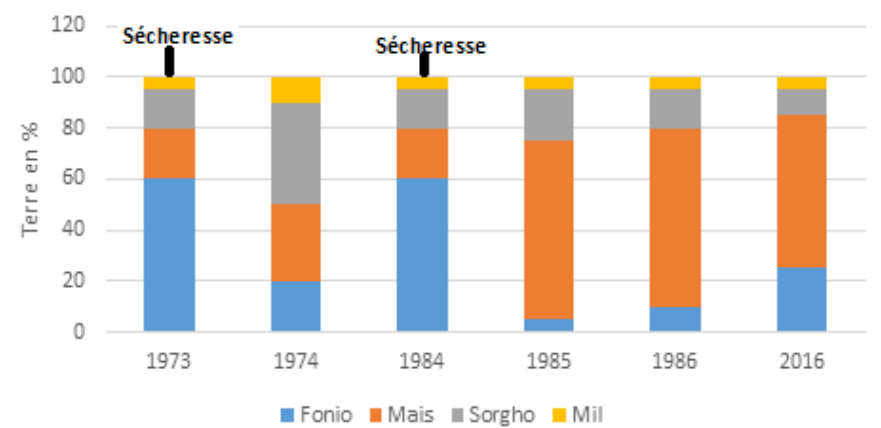

Fig. 3: Distribution rate of household land between crops in Mandela.

\section{Changes in the hungry rice culture}

The visible changes and their origin according to the producers of hungry rice are recorded in Table 1. With the reduction of the height of rain, the longcycle traditional varieties (Mandela, Finiba) cultivated by the producers can no longer complete their cycle vegetative. Biomass and grain production has been significantly reduced. This has led women to opt for the introduction of new varieties adapted to the new rainfall situation of the soil. The Institute of Rural Economy and the cooperative of producers of hungry rice are conducting varietal adaptability tests. For nearly a decade, the rains received are very poorly distributed in the area. One side of the land can be sufficiently watered by the rain, while the other side receives no gout. This type of distribution can be repeated several times during a crop year. The first rains are received in late June early July instead of May. This shift in the onset of the rains has brought into the new soils and late sowing dates. Hungry rice fields are flooded for whole weeks and every other year ends with a drought at the end of the crop cycle.

The importance given to crops such as maize, sorghum, millet means that very often the heads of households allocate marginal lands to women for hungry rice cultivation. In crop rotations, hungry rice always comes at the end of cultivation on an exhausted, undeveloped soil that has been cultivated for 3 years (maize-sorghum-mil-hungry rice). In this rotation it is the corn alone that receives the organomineral fertilizer. The order of cultures has been changed by women. Hungry rice has taken the place of sorghum in many households so that it can benefit from the after effect of corn fertilization. Women are increasingly applying organic manure to land used in hungry rice cultivation.

When men took care of the hungry rice culture, their goal was to produce to support the household. All production was self-consumed. The success of the culture was through recourse to family work and mobilization of the family patrimony. With the revival of culture by women, the goal of culture has become the generation of income. Their production strategy is based on their ability to provide the necessary resources for the success of the crop. The self-help work disappeared with the abandonment of culture by men. They use a right to use family land, a wage labor, local inputs in the hungry rice culture. Hungry rice, which was essentially a subsistence crop, has become a cash crop over the years. Women sell their crops to meet their needs (ornaments, clothing, childcare, condiments, travel, school fees, health). Despite this place in the household, the hungry rice crop does not receive any funding (credit for the purchase of agricultural inputs and credit for marketing or processing) from agricultural management institutions. 
Table 1. Visible changes in hungry rice culture among Mandela women, Mali.

\begin{tabular}{llll}
\hline Ressources & Present situation & Natural causes & Human causes \\
\hline Cultivars & Cycle of the non adapted variety & $\mathrm{X}$ & \\
& Low plant development & $\mathrm{X}$ & $\mathrm{X}$ \\
& Use of traditional seeds & & $\mathrm{X}$ \\
Rain & Decrease in yield & $\mathrm{X}$ & \\
& Decrease & $\mathrm{X}$ & \\
\multirow{5}{*}{ Cultivated soil } & Slow start & $\mathrm{X}$ & $\mathrm{X}$ \\
& Sudden stop & $\mathrm{X}$ & $\mathrm{X}$ \\
& Marginal land & & $\mathrm{X}$ \\
Financial resources & Low fertility & & $\mathrm{X}$ \\
\multirow{5}{*}{ Human resources } & Unmanaged land & & $\mathrm{X}$ \\
& No campaign credit & & $\mathrm{X}$ \\
\hline
\end{tabular}

\section{Using hungry rice straw}

The weight of straw produced by women varies between $800-1000 \mathrm{~kg} / \mathrm{ha}$. This straw has several uses: it is mixed with banco for the construction of houses. It is burned to obtain potash that goes into the preparation of a traditional meal. Fodder and glumes (residues after decorticating hungry rice) are used in animal feed. Only 15-20\% of the amount of straw produced in the soil is used in animal feed. In traditional medicine, its infusion is used in the massage of sprains and aches. Currently residues after shelling are dearly bought by breeders (1000 FCFA / kg). Between neighboring soils, there is a pact of use of the hungry rice straw. Straw that has remained in the field for more than a month, can be collected by a native or non-native to meet his or her own needs.

\section{Hungry rice performance evaluation}

There are three technical systems dominate hungry rice cultivation in the Mandela soils: The hungry rice cultivation without chemical or organic inputs, hungry rice cultivation following maize and hungry rice cultivation receiving organic manure (Table 2 ).

Table 2. Yield of traditional hungry rice varieties in different plots among women in Mandela, Mali.

\begin{tabular}{lllll}
\hline \multirow{2}{*}{ Year } & Grain yield kg / ha & & \\
\cline { 2 - 5 } & Control field & $\begin{array}{l}\text { Rotation of maize- } \\
\text { hungry rice }\end{array}$ & $\mathbf{2}$ t of manure / ha & $\begin{array}{l}\text { Mean standard } \\
\text { deviation }\end{array}$ \\
\hline $2014(\mathrm{n}=7)$ & 200 & 329 & 471 & 44 \\
$2015(\mathrm{n}=9)$ & 233 & 478 & 578 & 49 \\
$2016(\mathrm{n}=11)$ & 191 & 396 & 609 & 38 \\
Average & 208 & 401 & 553 & \\
\hline
\end{tabular}

The first system is a self-fertilizing system (rot of the root system and part of the aerial mass, nutrient uptake through dust winds). The second (the hungry rice crop coming after maize) and the third one (the contribution of $2 \mathrm{t}$ of manure / ha) respectively improved the hungry rice yield by $48 \%$ and $62 \%$. The impact of organic fertilization by women is significantly more significant. It is manure from any source that they themselves prepare in a corner of the yard of the house or out of the house. They mix faeces of small and large ruminants, poultry droppings and household waste that they spray with wastewater from the kitchen. This manure is divided between field of hungry rice and the parcel market gardening.

The corn-hungry rice rotation system is a system highly dependent on the chemical fertilizer $(100 \mathrm{~kg}$ 
of DAP / ha and 5-10 t of compost in bottom fertilizer at sowing, $150 \mathrm{~kg}$ of urea / ha in 2 spreadings: 1st half to the run and 2nd half to the female bloom). In this system, hungry rice benefits from the residual effects of fertilization on maize.

Compared to the control field, a hungry rice farmer growing hungry rice after maize will earn 33,775 FCA / ha. While the one who brings his organic manure will earn 60375 FCA / ha. In all three plots, the producer spends on harvesting and ginning operations. To produce hungry rice within the limits of its financial means would be at the base of the smallness of the surfaces exploited. Because women lack the resources to engage in hungry rice cultivation over large areas. In the rotation system, the corn field belongs to the household head who performs the maintenance and harvesting operations. This is the year after maize is used by women to produce their hungry rice.

Table 3. Gross income achieved in hungry rice cultivation among Mandela women, Mali.

\begin{tabular}{llll}
\hline & Witness & Rotation of maize-hungry rice & Supply of 2t of FO / ha \\
\hline Average yield kg / ha & 208 & 401 & 553 \\
Gross income FCFA / ha & 36400 & 70175 & 96775 \\
\hline
\end{tabular}

The kg of hungry rice grain at harvest $=175$ FCFA

The different income earned by women is linked to the market price, a price that women do not know. That's why they sell their crops to satisfy urgent needs. The women of Mandela were able to recover the hungry rice culture which has become a crop rooted in the culture of the communities with weekly treats often accompanied by balafon parties. Because of the decline in production, women have suspended these feasts.

Abrupt rains, excessive rains and floods of hungry rice fields and lack of advisory services are among the reasons for this drop in production. Many researchers predicted this change in the climate (Buontempo, 2010). And these climatic variables are likely to jeopardize the livelihoods of producers (Boureima et al., 2012).

In the first technical system of hungry rice without fertilizer, the hungry rice did not benefit from a financial investment allowing him to improve his yield up to wish. In the second it is the crop at the head of rotation (maize) that benefits from resource allocations. The direct beneficiary of this system is the head of the household. The last system does not also benefit from financial investment. This lack of investment and public support has reduced the attractiveness of the hungry rice cultivation in the field. It is the citrus fruits, the cultivation of cotton, corn, sorghum, millet, which attract more peasants.
Women and some young girls are the only ones to take care of hungry rice cultivation and the fact that men and boys do not participate raises the problem of generational succession in the household. Mandela's local women are learning how to organize a socio-technical, economic and cultural activity that has, no doubt, a considerable impact on the family and local economy (Barbedette, 2004; Bainville, 2000). They try to take into account all the visible changes in the hungry rice culture. There remains the institutional and financial support of local decision makers and development agencies that women are starting to negotiate through their association. Women, while playing their role in the family and in the community, undertake initiatives and actions to mitigate the effects of the changes they encounter in the production of hungry rice . These activities leave intact the family social structure and preserve the family farming that the head of the family runs. The women thus ensure the continuity of the hungry rice culture in the soil despite the consecutive droughts.

\section{Conclusion}

The hungry rice is a culture practiced in the soils of Mandela. Climate change has brought changes in this culture. It is women who have taken over from men and they produce hungry rice on small plots. They are faced with problems of crop 
abandonment, feminization of hungry rice cultivation ( $100 \%$ cultivation by women and girls), supply of agricultural inputs (fertilizers, seeds). The development of the hungry rice culture in the Mandela terroir, requires the development of a partnership between several institutions: agricultural research, finance, communication, agricultural extension, input suppliers, exporting traders and cereal processors. In this partnership, women will be sensitized and trained on new technologies. They will learn the planning, execution and evaluation of their activities in hungry rice production.

\section{Conflict of interest statement}

Authors declare that they have no conflict of interest.

\section{References}

Ba S., 2013. Agriculture familiale et les défis du changement climatique en Afrique. 1ière Édition Agriculture, changement climatique et responsabilité des organisations. Dakar, du 25 au 27 Avril 2013 au CICES. Contact EndaPronat: sidyba2002@yahoo.fr

Bainville S., 2000. Le développement de l'agriculture familiale : processus d'interactions entre changements techniques et changements institutionnels. Un " cas d'école " : la commune de SilvâniaBrésil. Thèse. Ecole Nationale Supérieure Agronomique de Montpellier, Montpellier, $253 \mathrm{p}$.

Barbedette L. 2004. Mieux connaître la réalité de l'exploitation familiale ouest-africaine DDC Coopération Suisse au développement. Section Afrique Occidentale $32 \mathrm{p}$.

Boureima, M., Abasse, A.T., Sotelo Montes, C., Weber, J.C., Katkoré, B., Mounkoro, B., Dakouo, J-M., Samaké, O., Sigué, H., Bationo, B.A., Diallo, B.O. 2012. Analyse participative de la vulnérabilité et de l'adaptation aux changements climatiques: un guide méthodologique. Occasional Paper 19. Nairobi: World Agroforestry Centre. West and Central Africa Region ICRAF-WCA/Sahel
Buontempo C. 2010. Sahelian climate: past, current, projections. Met Office Hadley Centre, Devon, UK.

CILSS, 2012. Rapport sur la situation agricole et alimentaire au sahel et en Afrique de l'ouest. Réunion de haut niveau sur la Crise Alimentaire et Nutritionnelle des Etats Membres de la CEDEAO, de l'UEMOA et du CILSS. 16 pages.

CPS/SDR, 2015. Annuaire statistique/Secteur du Développement Rural. Ministère de l'Agriculture. MALI. 133 pages.

Consortium AGRECO 2014. Révision du profil environnemental du Mali. Rapport final. Contrat-cadre bénéficiaires 2013-Lot No 6 Environnement/Europe

Aid/132633/C/SER//multi- Contrat Spécifique No 2014/342864. 172 pages

CTA, 2014. Renforcer la résilience de l'agriculture familiale. ICT Update numéro 78, août 2014. Magazine web (http://ictupdate.cta.int).

Gichangi E.M., Njiru E.N., Itabari J.K.,Wambua J.M., Maina J.N. and Karuku A. 2007. Assessment of improved soil fertility and water harvesting technologies through community based on-farm trials in the ASALs of Kenya. In: Advances in Integrated Soil Fertility Management in Sub-Saharan Africa: Challenges and Opportunities (Ed.: Bationo, A.). J. Nutr. Cycl. Agroecosyst. 76, 759-765.

Kieft H., N. Keita et van der Heide 1994. Engrais fertiles? Vers une fertilité durable des terres agricoles au Mali. 99 p. ETC, Leusden, The Netherlands.

Ministère de l'Agriculture, 2007. Recensement général de l'agriculture (RGA) Campagne Agricole 2004-2005. Vol. II: Rapport Détaillé. Projet GCP/INT/903/FR « Appui au Programme de Renforcement des Systèmes d'Information et de Statistiques Rurales en Afrique ». 98 pages

Okalebo J.R., C. O. Othieno, P. L. Woomer, N. K. Karanja, J. R. M. Semoka, M. A. Bekunda, D. N.Mugendi, R. M. Muasya, A. Bationo and E. J. Mukhwana 2007. Available technologies to replenish soil fertility in East Africa. In: Advances in Integrated Soil Fertility 
Management in Sub-Saharan Africa: Challenges and Opportunities (Ed.: Bationo, A.). J. Nutr. Cycl. Agroecosyst. 76, 45-62.

Tabo R., Bationo A., K Diallo Maimouna, O Hassane and S Koala 2005.Fertilizer MicroDosing for the Prosperityof Small-Scale
Farmers in the Sahel. Final ReportJune 2002 December 2004/Final Report/Submitted to the United States Agency for International Development/ ICRISAT-International Crops Research Institute for the Semi-Arid Tropics.

\section{How to cite this article:}

Sogodogo, D., Coulibaly, B., Sanogo, M. D., Dembélé, D., Sanogo, S., 2017. Resilience of hungry rice cropping in Sudano-Guinean area of Mali: Case study in the village of Mandela. Int. J. Curr. Res. Biosci. Plant Biol. 5(1), 10-17. doi: https://doi.org/10.20546/ijcrbp.2018.501.002 